\title{
The Evolving Transformations of Disability in Dubai Between 1980 and 2012
}

\begin{abstract}
To examine the transformation of disability policy in the city of Dubai is to examine how the daily lives of people with disabilities are affected by these policies. This chapter explores in detail the evolution of disability policy in Dubai between 1980 and 2012 in two parts. The first explores the concept of urban transformation by highlighting the role that key legal, political, social, and cultural events played in shaping the evolution of disability services leading up to my first visit to Dubai in 2007. The second offers discussion of empirical findings from extensive fieldwork I conducted between 2007 and 2012. Findings were derived from numerous interviews, surveys, and focus groups aimed at answering the following questions: What steps have planners and policymakers taken to make Dubai more inclusive of people with disabilities, what impact has this had, and what broader lessons can be drawn from the experience?
\end{abstract}

Keywords Participatory action research • Ethnography • Anthropology of the state $\bullet$ Disability studies $\bullet$ UAE history $\bullet$ Evolution of public policy $\bullet$ Medical model $\bullet$ Qualitative methods for disability policy research 


\section{INTRODUCTION}

On November 10, 2013, the Crown Prince Sheikh Hamdan Bin Mohammed $\mathrm{Al}$ Maktoum made an unexpected and bold announcement, "Sign language and braille will be commonplace in Dubai by 2020" (WAM 2013). Dubai-a city for business, luxury, and status - would, according to the Ruler's Media Office, be transformed into a "city for everyone" ("Dubai will be a place for everyone, says Sheikh Hamdan," 2013). I remember thinking at the time that if his declaration proves true, Dubai would in the span of seven years be transformed into an inclusive city, a city where "all responsible service bodies" work to construct "a city welcoming to people with disabilities" (WAM 2013). I was eager to find out how such a complete transformation could possibly occur so quickly.

This was a particularly interesting proposition because in the six years prior (between 2007 and 2012), I documented the rapid rate of urban development and the entrepreneurial and competitive spirit of Dubai. Would best practices in architecture and urban design transform Dubai into the world's most disability-friendly city? I was not so sure, but that goal had deep roots. Designers, planners, and policymakers often fail to adequately consider the evolving transformation of disability and the historical trajectory of how disability is understood and defined socially.

This chapter narrowly focuses on the policies and histories that shape the lived urban experiences of persons with disabilities in the city of Dubai between 1980 and 2012. Although the wider forces of globalization, trade, and commerce clearly affect the urban experiences of diverse constituents, this book will not attempt to detail the implications of Dubai's economic transformation during this period. Other scholars, including Davis and Monk (2007), Davidson (2008), Krane (2009), Salem (2016), Akhavan (2017), Hannam (2018), and De Jong et al. (2019), have all previously explored the economic, geopolitical, and physical transformation of Dubai as a rising global metropolis. Instead, here I focus on the social context of access and inclusion for people with disabilities and the interceding urban transformation during a critical period of economic and institutional change.

This book situates disability policy as the primary unit of analysis within key social institutions to illustrate how Dubai's political and urban transformations shape and are shaped by the people, processes, histories, organizations, policies, and attitudes toward disability. Extensive fieldwork, including interviews, surveys, and focus groups conducted in Dubai 
between 2007 and 2012, was aimed at answering the following questions: What steps have planners and policymakers taken to make Dubai more inclusive of persons with disabilities, what impact has this had, and what broader lessons can be drawn from the experience?

While the interrelated concepts of equity, empowerment, accessibility, and inclusion are foundational to the field of urban planning, their application to disability rights is virtually absent in the planning literature. This is especially troubling when we consider the large amounts of literature developed in the burgeoning field of disability studies. There is wide consensus that individuals with disabilities in most major cities confront seemingly insurmountable obstacles when interpreting signage, identifying the presence bus stops, navigating through poorly planned streetscapes, or generally moving around cities without assistance.

In this book, the adjective inclusive strictly denotes inclusive of persons with disabilities. Thus, an inclusive city is one where public services are provided on an equitable basis to persons with and without disabilities. An accessible city is inclusive because accessibility allows people to enjoy the same range of rights, privileges, and services regardless of their gender, race, class, age, or impairment. Defining an inclusive city this way also implies that an inclusive city promotes equity, empowerment, and accessibility as stipulated in the United Nations (UN) Convention on the Rights of Persons with Disabilities (CRPD). It should be no surprise that these concepts are transformative and, when implemented, demonstrate how "rights to the city" function in practice.

This chapter is structured into two parts. The first part explores the concept of transformation by highlighting for the first time the legal, political, social, and cultural evolution of disability services in the Emirate of Dubai during its early development between 1980 and 2006. The second part offers a short discussion of empirical findings from fieldwork conducted during the height and slowdown of its growth, namely between 2007 and 2012.

\section{A City for Some or for Everyone?}

Proponents of disability rights may initially be skeptical of Dubai's "City for Everyone Initiative." According to Ahmed M., a leading architect working for Dubai Municipality, "transforming a city from a construction site to a universally designed city is not an easy task" (personal communication, October 20, 2009). However, he is quick to note that "Dubai has 
proven the naysayers wrong before." $\mathrm{He}$ is referencing the dramatic changes that Dubai has experienced in prior 30 years. Between 1978 and 2008 Dubai was transformed from a sleepy fishing village into a bustling metropolis with world-class attractions such as museums, theme parks, malls, holiday resorts, exclusive communities, wellness hotels, and festival markets (Dehaene and De Cauter 2008; Edensor and Jayne 2011). The ruling family, the Al Maktoums, achieved many of the seemingly improbable goals for the city that they indicated they would: construction of the world's tallest building and largest shopping mall, as well as the Palm Jumeirah development, a $7 \mathrm{~km}$ long man-made island that takes the shape of a palm tree (Staff 2008, 2010c, d, e). The government has dramatically improved health outcomes, lowered mortality and morbidity rates, and positioned Dubai as the "City of Tomorrow." Despite these remarkable feats of urban and social development, little is known of how these urban transformations affect the lives of persons with disabilities.

According to the Khaleej Times, the "City for Everyone" initiative launches a new legislative framework. The initiative will develop public and private sector projects that improve public services and infrastructure for people with disabilities. Specifically, these initiatives remove physical barriers and afford persons with disabilities access to all public sector services on an equal basis to persons without disabilities (WAM 2013). A "City for Everyone" would provide "excellent healthcare" to people with disabilities, as well as "supportive social services," and mandates that "all responsible parties" create a "broad societal awareness that contributes to integrating people with disabilities and confirms their participation in community development" (WAM 2013). The rationale for embarking on these ambitious changes is described as "backing the current efforts of Dubai to empower people with disabilities within an overarching framework that contributes to enhancing the effectiveness of existing projects." The article goes on to say that additional initiatives would maximize the participation and integration of this "category" in the community and create new opportunities through which to overcome all the obstacles that may stand in the way of positively engaging and integrating this segment in their social environment as individuals who possess productive and creative capabilities (WAM 2013).

The language used indicates that people with disabilities are a "category" or "segment" of people that must overcome obstacles preventing them from positively engaging in the broader community. This statement simultaneously sets out a vision and mandate that is at once both ambitious 
and vague. What are the specific obstacles to participation and what new opportunities will be created and by whom? How will the "City for Everyone" initiative succeed and who defines the metrics for its success? Who specifically will create these opportunities? How have planners and policymakers in Dubai designed and implemented opportunities for persons with disabilities in the past? If so, what results have they had? To answer these questions, we must uncover the existing legal, cultural, and historic precedents that can contextualize and add depth to the "City for Everyone." In the next section, I argue that Dubai's "City for Everyone" initiative is not in fact a new initiative; it is rather a purposeful and public re-commitment to fulfilling unmet public mandates, including national and international laws as well as basic local needs.

\section{A City of Laws, Needs, and International Obligations}

Dubai's international obligations complement its political commitment to disability issues. In 2008, Article 9 of the UN Convention on the Rights of Persons with Disabilities recognized accessibility as a human right. This legal instrument fundamentally influences the ways that cities are built, and leaders in Dubai have taken note. From London's full fleet of accessible black cabs to Paris' adoption of tactical museum tours for the blind and Sao Paolo's new accessible transportation master plan, the CRPD is increasingly reshaping urban life. ${ }^{1}$ In the 93 countries that have ratified the CRPD, including the United Arab Emirates (UAE), waves of urban and social reforms aim to dismantle pervasive architectural and attitudinal obstacles. Few scholars have set out to document how this golden wave of accessibility is actually being carried out.

The CRPD obligates cities to plan for and meet explicit goals. It reaffirms that all persons with all types of disabilities must enjoy all human rights and fundamental freedoms on an equal basis with others (United Nations 2006). The way cities understand discrimination toward persons with disabilities needs to change. According to the CRPD, local and national governments must protect their residents from discrimination on the basis of disability not only by passing laws but by changing attitudes. According to the former United Nations Special Rapporteur on Disability

\footnotetext{
${ }^{1}$ Additional global agreements such as the Sustainable Development Goals (2015-2030) and the upcoming Habitat III summit (2016) have clear statements mandating that cities be made more inclusive.
} 
Sheikha Hissa Al Thani, a member of the ruling family of the neighboring state of Qatar, "[d]isabled people are more marginalized and more isolated than other people...specifically in the Arab region; they are invisible, because of negative social attitudes" (Reini 2008). One clear example of how people with visual impairments are marginalized is recounted to me by a local advocate named Awatif; she noted in an interview, "the fact that we are denied the right to open a bank account is due to an outdated banking law. This law requires all clients to be able to read a written policy and sign on the dotted line" (personal communication, 2009).

Since 2005, the Ruler, Sheikh Mohammed bin Rashid Al Maktoum, has repeatedly stated that persons with disabilities should be given the support to allow them to contribute to the development of the nation on an equal basis with others (JIWIN 2007; Rains 2005a, b, c; Staff 2010a). The UN Special Rapporteur specifies that people with disabilities should be able to live in a city that entitles them "the same rights to work, education, and health care as everybody else - and granting these rights is a prerequisite rather than a concession [of governments]" (Reini 2008).

On September 12, 2006, and in response to the CRPD, the Supreme Council of the UAE enacted a landmark national law, Federal Law No. 29 (Staff 2009a, b, 2010b). ${ }^{2}$ That same day, Gulf News published an article titled "Law Removes Barriers for People with Special Needs" (Salama 2006). According to the article, the UAE's first law to protect the rights of people with disabilities was approved by President Sheikh Khalifa Bin Zayed Al Nahyan. According to Wafa Hamad Bin Sulaiman, Director of what at that time was the Department for People with Special Needs at the Social Affairs Ministry, the law was comprehensive, "matching international standards, providing equal rights, opportunities and choice for persons with disabilities" (Salama 2006). She indicated that Federal Law No. 29 removes all barriers to equal opportunities for persons with disabilities and guarantees their right to a decent life and comprehensive care in education, training, health, and rehabilitation (Salama 2006). The law, she said, guarantees an unspecified job quota for qualified individuals with disabilities in the public and private sectors, provides for improved accessibility to public buildings and residences, and integrates students with

\footnotetext{
${ }^{2}$ Federal Law No. 29 was inspired by the UN Convention on the Rights of Persons with Disabilities. Although the latter is more comprehensive in affording disability rights, Federal Law No. 29 provides essential rights for persons with disabilities. Federal Law No. 29 affects all seven emirates by mandating an ambitious set of civil codes affecting everything from workplace accommodations and accessible public transportation to inclusive education.
} 
special needs into public and private schools (Salama 2006). However, in the subsequent six years since the passage of the law, proponents for disability rights in Dubai bemoan that the Ministry of Social Affairs has failed to adequately implement the law. Khaled A., an Emirati lawyer, noted, "every city in the country, including Dubai, has wasted time" (Khaled A., personal communication, December 25, 2013). Jumana B., a special educator in Dubai, noted that by 2013 the city had made little progress in making schools, places of employment, government websites, and telecommunications infrastructure more accessible (Jumana B., personal communication, December 30, 2013). What were the factors that impeded progress? How could local institutions at various levels of government effectively respond to these mandates?

The CRPD and its local counterpart, Federal Law No. 29, differ significantly in their approach to social inclusion, and these differences ultimately affect the inclusiveness of city life. Both laws outline a range of actions and responsibilities and highlight the need for cross-sector cooperation. However, upon closer assessment, Federal Law No. 29 falls short on two accounts: it categorizes disability issues as a social protection issue instead of a human rights issue, and it fails to provide implementing agencies with specific regulations. As will be evident in later chapters this would be one of several fundamental institutional challenges to building a truly inclusive and accessible city.

\section{Historical and Cultural Dimensions of Disability IN DUBAI FROM 1980 to 2012}

\section{The Beginnings of Disability Services in the Emivate of Dubai (1980s-1990s)}

Interview subjects working in the government noted that specialized disability programs started in Dubai in the 1980s as the state made gains in its human development, most notably in increasing literacy and life expectancy. Several people interviewed indicated that disability services in the Emirate of Dubai started with the Al Noor Training Center for Children with Special Needs. The Al Noor Training Center opened its doors to its first eight students on November 21, 1981. Al Noor was not a residential facility but a daycare center, with a focus on skills development. It was a charitable entity that could not support the widespread demand for the types of services that it provided. Another center called Five Aces was also 
formed during this time. It was a residential facility set up in a rented villa by Jumeirah Beach that could accommodate five students. These two private care centers were the first to provide specialized care and educational services to children with disabilities but others would soon follow.

The Rulers of Dubai, Abu Dhabi, and Sharjah had developed their own efforts in forming "special needs" care centers and funded them from their own purses. In Dubai, H.H. Sheikh Rashid Bin Saeed Al Maktoum donated two beachside villas to form the Dubai Center for Special Needs. It was customary at the time for Rulers to personally respond to pleas from parents to build specialized medical, rehabilitative, and sports facilities for children with cerebral palsy, Down's syndrome, and other congenital or developmental disabilities. The Dubai Center for Special Sports (DCSS) obtained a large facility from the Ruler of Dubai, Sheikh Rashid Al Maktoum. The care provided to persons with physical or mental impairments was commonly offered based on tribal or family ties.

Government services such as more formalized medical care and social security grew to differing degrees in the 1980s as the state formalized its institutions. By the 1990s, H.H. Sheikh Ahmed Bin Rashid Al Maktoum, Commander-Military Command, donated 300,000 sq. ft. of land to build a new facility accommodating 200 students at a new Dubai Center for Special Needs. Additionally, in 1994, the Rashid Pediatric Therapy Center opened up services for what would eventually become 150 full-time students. At this time, there were new approaches being developed that focused on social inclusion and integrating mainstream services in other parts of the world; however, this was not occurring in the UAE. These specialized services were attempting to support students integrate into their communities. The challenge though was that they were not connected to general mainstream programs such as public school placements. While Dubai was making efforts during this time, persons with disabilities were still very marginalized and not achieving independence or job placements. Dubai had started the practice of developing specialized separate services for persons with disabilities but was unable to define, adopt, and regulate proper standards for service delivery.

\section{New Approaches to Disability Services Forming (1990s-2005)}

During this period, disability rights were maturing in different parts of the world. By 1996, the neighboring nation of Kuwait became the first country in the Gulf Cooperation Council to pass specific legislation addressing 
the education and care of persons with disabilities. By the late 1990s, the UAE was behind its neighbor Kuwait in many regards. ${ }^{3}$ During this time, the Kuwaiti government was steadily opening up spaces for civil society and advocacy groups to form. In contrast, the UAE controlled and censored civil society advocacy efforts (even on behalf of persons with disabilities). Kuwait formed a parliament and, through it, provided tempered support to key champions like Munira Al-Mutawa, the Founder and Secretary-General of Kuwait Society for the Handicapped. The UAE meanwhile was preparing for a massive expansion of its economy; it maintained a centralized approach that focused on expanding trade while simultaneously delaying reforms that would open political and public participation.

On October 8, 2009, during the first focus group I conducted with persons with disabilities, their parents, and allies in Dubai, parent advocates commented that their efforts in forming non-profit associations in the UAE were frustrated by the state bureaucracy. Additionally, they commented that conflicting policies toward public associations made it difficult to form advocacy and support groups. Dr. Eman Gaad, a professor of special education at the British University of Dubai and founder of the Emirates Down's Syndrome Association, agreed. She mentioned that the previous policies adhered to by the Ministry of Labor and Social Affairs at the time were so strict that they often prohibited families of children with disabilities from forming voluntary associations. Their budding associations for children with cerebral palsy, Down's syndrome, and others were thus weak and encountered legal obstacles to legitimacy, funding, and social recognition. According to Dr. Gaad, a handful of parent-run organizations such as the Down's Syndrome Association eventually formed through special permission and obtained support from the Ruler's office, but the support came with a cost. Civil society associations were heavily controlled and family associations faced roadblocks and bureaucratic hurdles in carrying out their activities. According to Awatif Ahmad Akbari, a respected disability rights advocate, there were no organizations in Dubai for persons with disabilities that were actually run by persons with disabilities until 2004. Awatif was one of the first leaders with a disability to run an organization that aimed to serve constituents facing the same types of challenges that she herself faced. Awatif has a visual impairment and was able to obtain a leadership

\footnotetext{
${ }^{3}$ According to conversations I had in 2009 at the Shafallah International Forum in Doha, Qatar, with local experts in the field of rehabilitation.
} 
role in Tamkeen, an innovative quasi-governmental initiative. Tamkeen means "enabling" in Arabic, and the organization was set up to empower people with visual impairments. In May 2004, Sheikh Mohammed bin Rashid Al Maktoum, Crown Prince of Dubai at the time, became the founding patron of Tamkeen.

Under his patronage the center became a unique model for an inclusive disability advocacy organization. Tamkeen was unique to Dubai not only because of its commitment toward social integration and empowerment of persons with visual impairments but also because of its governance. Of the three key figures behind the running of Tamkeen-Hamish Mckenzie, Awatif Ahmad Akbari, and Ahmad Almulla, both Awatif and Ahmed had visual impairments. According to Awatif, Tamkeen was one of the first organizations for persons with disabilities represented and run by persons with disabilities. ${ }^{4}$ Tamkeen sought to empower the visually impaired (both national and foreign born) through vocational training and leadership development. Awatif eventually went on to run Tamkeen and expand their programs.

\section{Disability Forms Part of the National Strategy (2005-2013)}

In December 2005, Sheikh Zayed Al Nahyan, the President of the UAE and Ruler of Abu Dhabi, approved a National Strategy that had the goal of establishing an integrated course of development across all the Emirates. This happened at the same time that the UAE, and specifically the Emirate of Dubai, was garnering attention from the explosive rate of urban expansion that was taking place. Dubai's boom signaled to UAE nationals and residents that nation-building efforts were well underway. During this time, government officials signaled their intent to use the UAE's economic development to also drive its social development. One of the primary areas of the National Strategy was social welfare. As a result, there would be an increased focus on disability programs and services.

Just as opportunities were opening for persons with disabilities on the planning front, there were also new opportunities occurring from within local and federal government. In 2006, Dubai underwent a major power shift when Crown Prince Sheikh Mohammed bin Rashid Al Maktoum took over the title as Ruler of Dubai and was appointed by the Supreme

\footnotetext{
${ }^{4}$ The only other notable exception was Al Thiqah Club in the neighboring Emirate of Sharjah.
} 
Council as Vice President and Prime Minister of the federal government. In the realm of disability rights, improvements on the ground were coming at an ideal time and with the support of a sympathetic leader. Sheikh Mohammed's cadre of advisors and confidants were assigned new posts and began signaling new opportunities for the country as well as new opportunities for persons with disabilities. Such signals sparked hope for more meaningful empowerment and engagement of disability organizations and their allies (Fig. 4.1).

Anissa Al Sharif, a UK-educated, local social policy expert, was working to support the Ruler's vision for Dubai at the time. She served as the Senior Social Policy Planner at the Dubai Executive Council and was tasked with drafting one of the four key pillars of the 2015 Dubai Strategic Plan. By this time, Anissa Al Sharif knew that there were many segments of the population that were being left out of the Dubai boom. She sought to develop a comprehensive report on the social development needs in the

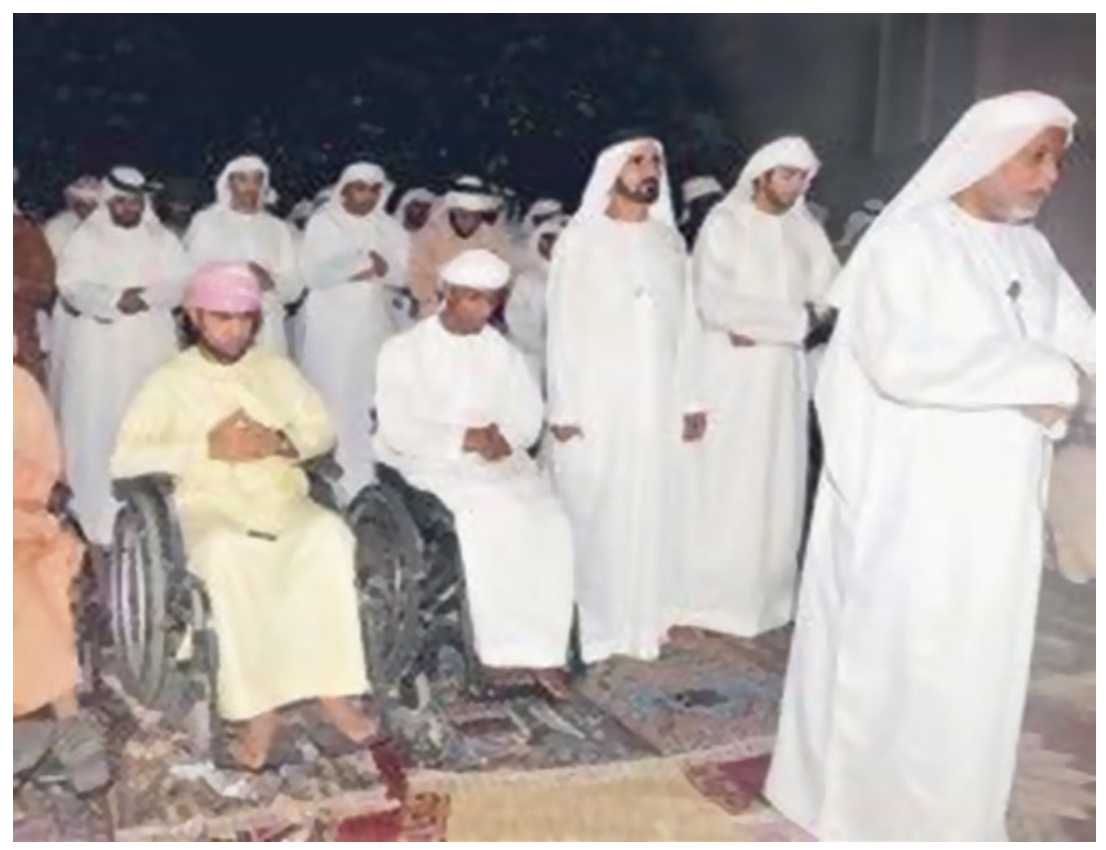

Fig. 4.1 Sheikh Mohammed during a 2009 Ramadan prayer in his majlis with young persons with disabilities as his guests 
Emirate of Dubai. Her study developed an empirical base from which social components of the Dubai Strategic Plan would be developed. According to Anissa Al Sharif, the 2015 Dubai Strategic Plan specifically emphasized the Emirate's commitment to empowering persons with disabilities.

Due to federal-level inertia the process of "decentralization" was well underway in 2006. As a result of the National Strategy, Dubai and Abu Dhabi were pouring hundreds of millions of dollars into building stronger local institutions. In Dubai, these local institutions were called authorities and were being formed under the auspices of Ahmad Bin Bayat, the Chairman of the Dubai Executive Council. Local authorities were charged with implementing the 2015 Dubai Strategic Plan (DSP). They promoted a new, more inclusive vision for Dubai-a vision that, because of the DSP, would include persons with disabilities. In Dubai, working on behalf of persons with disabilities was a family affair. Her Royal Highness Princess Haya Bint Al Hussein (the wife of H.H. Sheikh Mohammed bin Rashid Al Maktoum, Vice President, Prime Minister, and Ruler of Dubai) stated that children of determination were at the top of her priorities and their empowerment was a national duty (Rashid Magazine Therapy 2008, 20).

In February 2006, Dr. Miriam Al Roumi ${ }^{5}$ responded to this call when she was appointed Minister of the newly created Ministry of Social Affairs (Staff 2006). Her duty as Minister was to oversee social service reform at the federal level. According to social development expert Anissa Al Sharif, social security and social services in the UAE were at this time weak and relatively underdeveloped. She indicated that most ties in Dubai were traditionally tribal or family based. Cash transfers were distributed directly by individual Rulers. According to interviews up until 2007, the Rulers distributed such social support to petitioners from their personal wealth. This was a time of great institutional transformation, the development of a formalized social security system in the Emirates was only five years old, and local authorities, public policies, and programs were still being formed.

Since the appointment of a dedicated Minister for Social Affairs, Her Excellency Miriam Al Roumi managed a system of social protection that provided direct financial assistance to needy local families. Federal efforts

\footnotetext{
${ }^{5}$ Miriam Al Roumi had served as Undersecretary of the Labour and Social Affairs Ministry since 1999 and had previously run the special needs section at the ministry. She cites her experience in running and overseeing the special needs department as an important factor in supporting the creation of this law.
} 
continued to formulate laws to strengthen social protections mandated by CRPD Article 28. ${ }^{6}$ According to the UAE's National Report (Emirates 2008) submitted to the UN's Human Rights Council, the Ministry of Social Affairs provides a variety of support services and, by doing so, supports the basic human rights of its citizens.

Several interviewees (personal communication, April 20, 2007, and September 15, 2009) commented that between 2005 and 2006, the United Nations Convention on the Rights of Persons with Disabilities was being finalized in New York and, as a result, the UAE leadership wanted to quickly demonstrate to the international community its commitment to human rights. Notwithstanding the Minister's best intentions, many sources indicated that Federal Law No. 29 of 2006 encountered shortcomings from the time of its inception. Nonetheless, the law was enacted within the context of greater structural changes taking place in the Emirate of Dubai.

\section{Benefits for and Constraints in Implementing Federal Law No. 29}

Leading scholars, advocates, and public sector employees I spoke with between 2009 and 2012 indicate that the city and its policies were characterized as having "attention deficit and hyper-activity disorder." Without a local and federal strategy the government was not able to implement Federal Law No. 29 or tangibly push forward broader social development goals. Up until 2012, most federal-level actors benefited by publicizing their efforts as goodwill or simply as charitable initiatives. This approach is referred to as signaling, but these efforts were not conducted in concert or following any specific goal or strategy. Signaling, if not backed up by concrete actions, is a shortsighted tactic and by itself does not guarantee sustained involvement. In fact, it may prove counterproductive, as efforts are seen as tangential and not a central focus or explicit responsibility.

In this period, federal ministries spoke of consistent progress and cooperation but showed poor results. The key findings that characterize efforts between 2006 and 2012, in these first six years of Federal Law 29, include:

${ }^{6}$ Article 28 of the CRPD obligates nations to recognize the right of persons with disabilities to an adequate standard of living for themselves and their families, including adequate food, clothing, and housing, and to the continuous improvement of living conditions. Governments must take appropriate steps to safeguard and promote the realization of this right without discrimination on the basis of disability. 
1. Laws: Legislative measures characterize disability as a property of an individual independent of her/his physical or social environment. As such these early laws utilize language from the medical not the social or rights-based model of disability.

2. Leadership: Sufficient executive support but insufficient budgetary support exists in Dubai to realize the goals set forth in Federal Law No. 29.

3. Institutional Capacity: The UAE has sufficient administrative capacity but insufficient coordinating capacity to address disability more holistically in policy, planning, and design.

4. Attitudes: Social attitudes are strongly congruent with international norms along the dimensions of education, health, and employment, and incongruent along political and public participation, independent living, awareness raising, mobility, and accessibility.

5. Participation: Considerable social and institutional resistance precludes persons with disabilities from participating in public life.

\section{Analysis of Federal Institutions Implementing Federal Law No. 29}

What are the effects of institutional structures on the implementation of rights? Rights cannot be implemented in the Emirate of Dubai in a vacuum. Rights must be understood in the context of the local social, political, and economic structures that define the daily realities of all people. The ways these structures affect persons with disabilities in particular then become a new area for inquiry. Actors and institutions adjust in an opportunistic manner to shifting needs. In the next chapter we will see how Dubai's ability to continuously reform and restructure its institutions and processes provided a unique opportunity to create more inclusive and more responsive systems. The chapter describes and discusses the key functions and actions of federal and local actors in ensuring, protecting, and promoting the rights of people with disabilities along the following key areas: (1) capacity, leadership, and civil society; (2) regulations and process; and (3) implicit and explicit policy objectives as they relate to the implementation of Federal Law No. 29. 


\section{REFERENCES}

Akhavan, Mina. "Development Dynamics of Port-Cities Interface in the Arab Middle Eastern World-The Case of Dubai Global Hub Port-City." Cities 60 (2017): 343-352.

Davidson, Christopher M. "Dubai: The Vulnerability of Success," 2008, viii, 376viii, 376.

Davis, Mike, and Daniel Bertrand Monk. Evil Paradises: Dreamworlds of Neoliberalism. New York: New Press: Distributed by W.W. Norton \& Co., 2007. http://www.loc.gov/catdir/toc/ecip0713/2007010424.html.

De Jong, Martin, Thomas Hoppe, and Negar Noori. "City Branding, Sustainable Urban Development and the Rentier State. How Do Qatar, Abu Dhabi and Dubai Present Themselves in the Age of Post Oil and Global Warming?" Energies 12, no. 9 (2019): 1657.

Dehaene, Michiel, and Lieven De Cauter. Heterotopia and the City: Public Space in a Postcivil Society. Routledge, 2008.

Edensor, Tim, and Mark Jayne. A World of Cities: Urban Theory Beyond the West. Routledge, London, UK, 2011.

Emirates, The United Arab, UAE Ministry of Foreign Affairs, and United Nations General Assembly. "NATIONAL REPORT SUBMITTED IN ACCORDANCE WITH PARAGRAPH 15 (A) OF THE ANNEX TO HUMAN RIGHTS COUNCIL RESOLUTION 5/1." Abu Dhabi: UAE Ministry of Foreign Affairs, 2008. http://www.ohchr.org/EN/HRBodies/UPR/Pages/AESession3.aspx.

Hannam, Kevin. "Mobilities and Eventization: Dubai as a City of Speed." Via. Tourism Review, no. 14 (2018).

JIWIN. "HH Sheikh Mohammed Bin Rashid Honours 25 Government Employees: Recognizing Dubai's Unsung Heroes." Zawya, no. May 14, 2007 (2007): 2 .

Krane, Jim. Dubai: The Story of the World's Fastest City. Atlantic Books Ltd, 2009. Rains, Scott. "Dubai Makes a Move Toward Inclusion." Rolling Rains Report: Precipitating Dialogue on Travel, Disability, and Universal Design, no. June 13, 2005 (2005a). http://www.rollingrains.com/archives/000529.html.

_ . "Mohammed Bin Rashid Al Maktoum of Dubai: A Fair Sheikh for Travelers with Disabilities." The Rolling Rains Report, no. June 19, 2005 (2005b). http://www.suite101.com/article.cfm/travel_with_disabilities/116552.

- .Why Dubai?" Rolling Rains Report: Precipitating Dialogue on Travel, Disability, and Universal Design, no. June 8, 2005 (2005c). http://www.rollingrains.com/archives/000531.html.

Reini, James. "Arab Region 'Lacks' Disability Awareness." The National, no. September 3, 2010 (2008): 4.

Salama, Samir. "Law Removes Barriers for People with Special Needs." Gulf News, no. September 12, 2006 (2006): 3. 
Salem, Fadi. "A Smart City for Public Value: Digital Transformation Through Agile Governance-The Case of 'Smart Dubai'." World Government Summit Publications, Forthcoming, 2016.

Staff. "Call to Integrate the Disabled." The National, no. December 13, 2008 (2008): 1 .

_. "Dubai Metro Lifts 30mn Passengers in Initial Year, Meets Global Safety Standards." UAE Interact, 2010a, 1.

- "HH Sheikh Hamdan Bin Mohammed Bin Rashid Al Maktoum, Chairman of the Dubai Executive Council Launched Takamul, a Far-Reaching Initiative That Aims to Empower People with Special Needs." AME Info, 2006. http://www.ameinfo.com/95902.html.

_ "Khalifa Ratified Convention on the Rights of People with Disabilities." The National, no. December 26, 2009 (2009a): 1.

- "MoE Launches General Rules for Special Needs Students." UAE Interact, $2010 \mathrm{~b}, 1$.

—. "Mohammed Bin Rashid Issues Ordinance Regulating Private Institutions for the Rehabilitation of the Disabled." UAE Interact, 2010c. http://www. uaeinteract.com/docs/Mohammed_bin_Rashid_issues_ordinance_regulating_private_institutions_for_the_rehabilitation_of_the_disabled $/ 40680 . \mathrm{htm}$.

_. "People with Special Needs Will Be Entitled to Half-Price Travel on TransAD Taxi Fleet." UAE Interact, no. Disability (2010d): 1.

- "Sheikh Khalifa Ratifies Disability Convention." The National, no. December 25, 2009 (2009b): 1.

- "UAE Deposits with UN the Instrument of Its Ratification of the Convention on the Rights of Persons with Disabilities." Emirates News Agency, no. March 19, 2010 (2010e): 1.

Therapy, Rashid Pediatric. "Rashid Center Releases Story Series to Highlight Special Needs Issues." Rashid Magazine, 2008.

United Nations. Convention on the Rights of Persons with Disabilities and Optional protocol (2006). http://www.un.org/esa/socdev/enable/documents/tccconve.pdf.

WAM. "Dubai will be a place for everyone, says Shaikh Hamdan". Khaleej Times (2013). https://www.khaleejtimes.com/nation/government/dubai-will-bea-placefor-everyone-says-shaikh-hamdan. 
Open Access This chapter is licensed under the terms of the Creative Commons Attribution 4.0 International License (http://creativecommons.org/licenses/ by $/ 4.0 /$ ), which permits use, sharing, adaptation, distribution and reproduction in any medium or format, as long as you give appropriate credit to the original author(s) and the source, provide a link to the Creative Commons licence and indicate if changes were made.

The images or other third party material in this chapter are included in the chapter's Creative Commons licence, unless indicated otherwise in a credit line to the material. If material is not included in the chapter's Creative Commons licence and your intended use is not permitted by statutory regulation or exceeds the permitted use, you will need to obtain permission directly from the copyright holder.

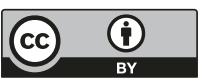

